Twenty-four years ago, the US government was also trying to attract young people into STEM (T. Packard Eos 70, 709; 1989). Then, $66 \%$ of the ocean-science community was living hand-tomouth on short-term government grants. A university professor was expected to do 40 hours of teaching and administration a week, and 40 hours of research. Researchers who did not receive funding from their universities dared not spend time away from their work, lest their publication record should drop.

It was clear to me at the time that if research centres, universities, governments and societies wanted more people to work in science and technology, then salaries, job stability and job security would have to improve. They still have not.

Young people continue to shun research and instead opt to use their mathematical skills in accounting, their analytical skills in investment banking and their love of science in medicine. Macilwain blames business for the woeful range of scientific opportunities available to graduates. Whether the fault lies with business, government or universities, the educational pipeline in science and engineering does not work because graduates are scared off by what they see as a meat grinder at the other end.

Theodore T. Packard University of Las Palmas de Gran Canaria, Spain. theodore.packard@ulpgc.es

\section{Education: science literacy benefits all}

Colin Macilwain wields too wide a brush in painting US federal funding of STEM education (for promoting 'science, technology, engineering and mathematics') as having the sole purpose of bolstering the workforce (Nature 497, 289; 2013). This funding also achieves general science literacy, particularly when it is directed towards children in primary and secondary education or undergraduate students.

No matter how far they are pushed, most teens and young adults will not become scientists.
Fortunately, many STEM programmes familiarize students with the scientific process and with the natural world. Learning fundamental concepts also teaches them how to interpret and handle scientific information.

Science literacy subsequently benefits individuals throughout their lives, from forming opinions about proposed government policies to making health-care decisions. A wellinformed citizenry, in turn, pays dividends to society as a whole.

Aaron C. Hartmann University of California, San Diego, USA. achartma@ucsd.edu

\section{Climate and war: a call for more research}

The possibility that climate change could be responsible for violent conflict (A. Solow Nature 497, 179-180; 2013) is starting to influence how governments frame and react to climate change. However, a real problem in this area is a paucity of theory to explain the associations (if any) between climate change and the outbreak of violence.

One overlooked factor is that populations caught up in conflicts or living in post-conflict societies are often more vulnerable to climate change. For example, the presence of landmines makes productive land inaccessible.

Climate policies can themselves be a source of conflict (see go.nature.com/zutmox). Measures that manage carbon sources and sinks or treat them as commodities - such as land-use changes, hydropower development or initiatives to reduce emissions from deforestation - can stimulate civil unrest if implemented without adequate checks.

Poverty, a history of fighting, and weak governance are well-established risk factors for conflict. The likelihood of violent conflict is reduced by democracy, social protection, effective justice systems and the protection of property rights. The influence of climate change on these factors warrants further investigation to guide policymakers in promoting peace and prosperity in a changing climate.
Neil Adger University of Exeter, UK. n.adger@exeter.ac.uk Jon Barnett University of Melbourne, Victoria, Australia. Geoff Dabelko Ohio University, Athens, USA.

\section{Climate and war: no clear-cut schism}

We are sceptical about the effectiveness of Andrew Solow's proposals for cooling the debate over a possible link between wars and climate change (Nature 497, 179-180; 2013). We think that the division between the two sides ('quants' versus 'quals') is not as clear-cut as he implies.

Solow argues that this dividing line distinguishes between those who search for connections between violence and natural phenomena, including climaterelated factors (quants), and those who prefer to explain conflicts as social processes (quals). But both approaches are studied by quants as well as quals. Quants may study climate-related effects on conflicts by analysing single events in detail or by considering many wars on aggregate using statistics.

There are also strong disagreements among those on each side of Solow's dividing line. For example, quants as well as quals include both proponents and sceptics of the connections between climate change and violent conflict.

In our view, the true divide is not so much about substance as about perspective.

Michael Brzoska, Jürgen

Scheffran University of

Hamburg, Germany.

brzoska@ifsh.de

\section{Gender equality in Australian academies}

Women are not underrepresented across all learned academies in Australia (see Nature 497, 7 and Nature 497, 439; 2013). For example, the Australian Academy of Technological Sciences and Engineering (ATSE; of which I am president) has taken steps to ensure that women are appropriately recognized and included in all its activities.
Gender imbalance can adversely affect all stages of a scientific career, from tertiary education to employer recruitment, retention and promotion, with implications for a country's productivity and prosperity. Over the past three years, ATSE has led the way in identifying and promoting female talent across the science and technology sector in Australia, and within the academy itself.

One key element of ATSE's gender-equality policy is to identify women candidates for fellowship nomination through active search and mentoring processes. Last year, 10 of 37 elected fellows were female, and women now comprise $40 \%$ of ATSE's governing board.

Alan Finkel ATSE, Toorak, Australia. alan@finkel.net

\section{European concerns over GM salmon}

As investigators for the European Food Safety Authority into the environmental risks posed by genetically modified (GM) fish, we are concerned about the US Food and Drug Administration's imminent approval of GM salmon (Nature 497, 17-18; 2013).

This is a huge step that could encourage aquaculture of other GM fish in other countries, and not necessarily under strictly biosecure conditions.

There is still considerable uncertainty surrounding the environmental and physiological effects of escaped, fast-growing GM fish on aquatic systems. This reflects a poor understanding of how different species might be affected as the modified gene is expressed in the wild.

Europe's regulatory guidelines for aquaculture of GM fish and other alien species in Europe will therefore be underpinned by rigorous risk assessment (see go.nature.com/p6x2qb).

J. Robert Britton Bournemouth University, Poole, UK.

Rodolphe E. Gozlan

Bournemouth University, Poole, $U K$; and Institut de Recherche pour le Développement (UMR 207), Paris, France. rudy.gozlan@ird.fr 